\title{
Small molecule targeted NIR dye conjugate for imaging LHRH receptor positive cancers
}

\author{
Jyoti Roy ${ }^{1,2}$, Miranda Kaake ${ }^{2}$ and Philip S. Low ${ }^{1,2}$ \\ ${ }^{1}$ Purdue Institute for Drug Discovery, Purdue University, West Lafayette, IN 47907, USA \\ ${ }^{2}$ Department of Chemistry, Purdue University, West Lafayette, IN 47907, USA \\ Correspondence to: Philip S. Low, email: plow@purdue.edu \\ Keywords: luteinizing hormone releasing hormone receptor; fluorescence-guided surgery; optical imaging; cancer imaging; \\ gonadotropin-releasing hormone receptors \\ Received: September 18, $2018 \quad$ Accepted: December 12, $2018 \quad$ Published: January 04, 2019 \\ Copyright: Roy et al. This is an open-access article distributed under the terms of the Creative Commons Attribution License 3.0 \\ (CC BY 3.0), which permits unrestricted use, distribution, and reproduction in any medium, provided the original author and source \\ are credited.
}

\section{ABSTRACT}

Overexpression of Luteinizing Hormone Releasing Hormone Receptor (LHRH-R) in various cancers and restricted expression of the receptor in healthy cells qualifies it as a valuable cancer biomarker. Previously, LHRH-R targeted peptides have been utilized to deliver attached payloads to LHRH-R expressing cancers. We report here for the first time the utilization of a small molecule non-peptidic ligand (BOEPL) of LHRH-R to deliver attached payloads to LHRH-R positive tumors. For this purpose, we linked the BOEPL ligand to a near infrared dye via various linkers. In vitro, these conjugates demonstrated low nanomolar binding affinity and in vivo they exhibited receptor-mediated uptake specifically in tumor tissue. Moreover, tumor uptake could be blocked by administration of excess unlabeled conjugate, and time course experiments showed retention of the dye conjugate in the tumor up to $12 \mathrm{~h}$ post injection. Because uptake of BOEPL-targeted NIR dye conjugates by nonmalignant organs/tissues was negligible and since the transient presence of targeted NIR dye in the kidneys was a result of clearance mechanism, we suggest that a BOEPL-targeted NIR dye might constitute a useful agent for fluorescence-guided surgery of LHRH-R positive cancers. Moreover, our results also provide proof of concept that BOEPL can be successfully used to deliver attached payloads to LHRH-R positive tumors in vivo.

\section{INTRODUCTION}

Luteinizing hormone releasing hormone receptor (LHRH-R; aka gonadotropin-releasing hormone receptor) is expressed primarily in the pituitary gland where its activation promotes the biosynthesis and secretion of both luteinizing hormone $(\mathrm{LH})$ and follicle stimulating hormone (FSH) [1-3]. The consequent systemic increase in LH and FSH levels induces survival/proliferation of reproductive tissues and the synthesis and release of testosterone and/or estrogen. Because these gonadal steroids further stimulate both growth and survival of cells in the mammary glands, ovaries, prostate glands, and endometrium, the net consequence of LHRH-R activation is the expansion and differentiation of reproductive tissues [1-6].
LHRH-R is also significantly upregulated in $\sim 50 \%$ of hormone-dependent breast cancers $[7,8], \sim 86 \%$ of prostate cancers [9-11], $\sim 80 \%$ of endometrial cancers $[12,13]$, and $\sim 90 \%$ of ovarian cancers, $[12,14]$ where it is similarly believed to promote cell proliferation and survival. Moreover, LHRH-R is also over-expressed in many non-hormone dependent cancers, including cancers of the pancreas [15], skin [16], brain [17], kidney [18], and, liver [19]. Not surprisingly, efforts to treat LHRH-R positive tumors have focused on the development of antagonists that can block production of LH and FSH and thereby prevent the biosynthesis of androgens and estrogens that promote tumor growth.

Because of its limited expression in normal tissues [1], LHRH-R has also been exploited for the targeted delivery of both imaging and therapeutic agents $[20,21]$ 
to LHRH-R positive tumors. In some cases, antibodies or LHRH peptides that bind LHRH-R have been used to carry attached imaging agents (e.g. with ultrasound [22], MRI [23], PET [24], SPECT [25], or fluorescence [26] contrast agents) to LHRH-R expressing cells, while in other cases these peptidic targeting ligands have been employed to deliver chemotherapeutic agents $[21,27,28]$ to receptor expressing cells. Although the results of virtually all of these studies have demonstrated considerable promise, a limitation in most of the studies has been an unexpected off-target uptake in the liver and/or kidneys [22, 23].

Because neither the liver nor kidneys expresses significant levels of LHRH-R, we wondered whether the unpredicted accumulation LHRH-R targeted drugs in these organs might derive from the exclusive use of peptides/proteins as targeting ligands and the prominent expression of peptide scavenger receptors in both liver and kidneys [29, 30]. To examine this possibility, we elected to develop a non-peptidic LHRH-R ligand to determine whether it might avoid the unwanted uptake in kidneys and liver. In this paper, we report the first use of a non-peptidic LHRH-R ligand for delivery of attached payloads to LHRH-R positive cells. For proof of concept, we compare the uptake of our non-peptidic LHRH-R targeting ligand linked to a near infrared (NIR) dye in healthy and malignant tissues of mice implanted with various LHRH-R positive breast, ovarian, and endometrial cancer xenografts. We report here that incorporation of our non-peptidic LHRH-R targeting ligand into a ligandindocyanine dye conjugate enables accumulation of the fluorescent conjugate in the aforementioned tumors without promoting significant retention in either the liver or kidneys.

\section{RESULTS}

\section{Synthesis of NIR dye conjugates}

Two LHRH-R targeted NIR dye conjugates (Figure 1) were synthesized by first conjugating a modified LHRH-R antagonist (BOEPL) to one of two hydrophilic linkers via solid phase peptide chemistry, followed by coupling of the ligand-linker conjugate (BOEPL-L2, or BOEPL-L3) to an NIR dye (S0456), as described in Supplementary Figures 1 and 2. Because past experience has demonstrated that the properties of the linker can significantly influence the affinity, specificity and pharmacokinetics of the final ligand-linker-cargo conjugate [31], two different linker chemistries (i.e. PEG and peptidoglycan) were examined to determine which would yield the ligand-dye conjugate with the best properties.

In vitro binding affinity: The binding affinities of the NIR conjugates (BOEPL-L2-S0456, BOEPLL3-S0456) for breast cancer cells (MDA-MB-231) were first determined by measuring the cell bound fluorescence of each conjugate as a function of its concentration in the growth medium. The apparent $\mathrm{K}_{\mathrm{d}}$ of the BOEPL-L2-S0456 conjugate was found to be $10.1 \mathrm{nM}$, while that of BOEPLL3-S0456 was measured at $3.9 \mathrm{nM}$ (Figure 2). The fact

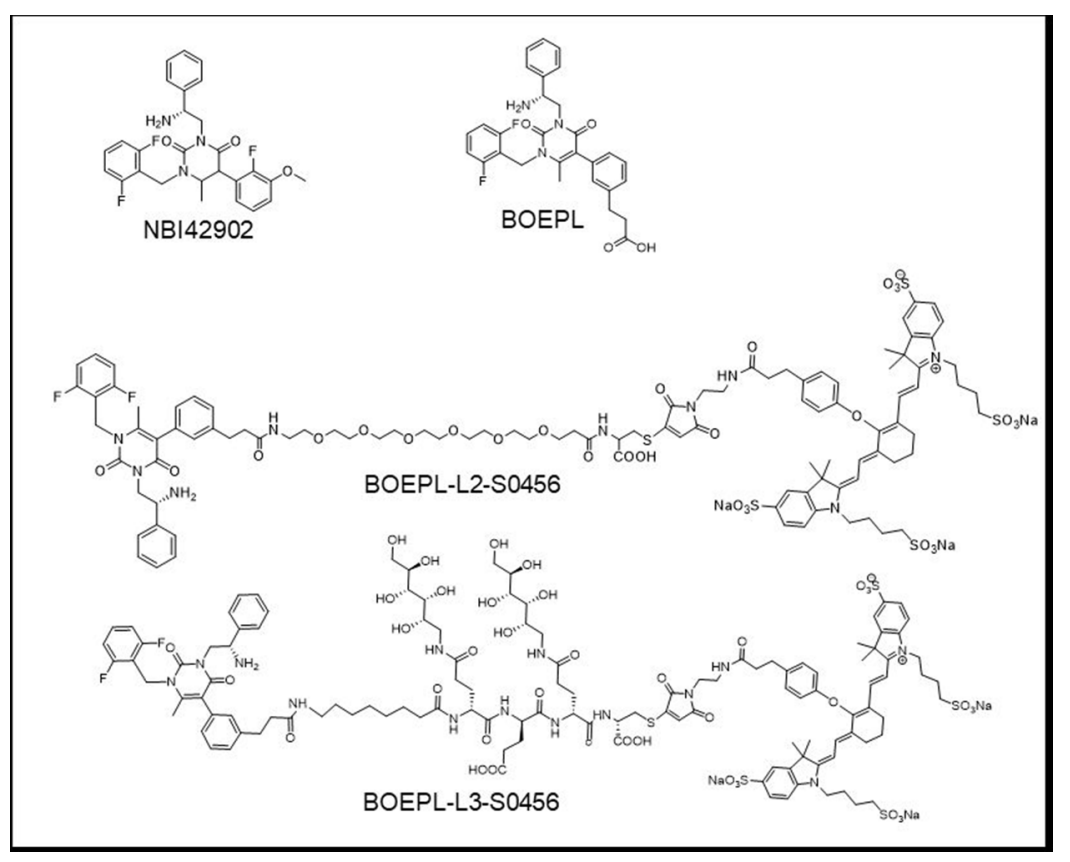

Figure 1: Chemical structure of LHRH-R targeting ligands and NIR conjugates: Structure of LHRH-R targeting ligands NBI42902 (ligand reported in the literature), BOEPL (modified ligand). Structure of LHRH-R targeted NIR dye conjugates: BOEPL-L2-S0456 (with PEG linker), and BOEPL-L3-S0456 (with peptidoglycan linker). 
that $\mathrm{K}_{\mathrm{i}}$ of the parent ligand is reported to be much lower $(0.19 \mathrm{nM}$ [32]) is consistent with previous observations that attachment of a linker to a ligand can often reduce the ligand's affinity for its receptor [31]. Nevertheless, the observations that the conjugate's affinity for its receptor is in the low nM range suggest that the conjugate's association with the cancer cells is of high affinity.

In vivo imaging and biodistribution: Since the NIR dye conjugates demonstrated high affinity and specificity for its receptor in vitro, we next investigated the ability of the above conjugates to target receptor positive tumors in vivo. For this purpose, mice bearing LHRH-R positive tumors (MDA-MB-231, OVCAR-3 or HEC-1B) were imaged with a near infrared fluorescence camera $2 \mathrm{~h}$ after intravenous injection of the LHRH-R targeted dye conjugates. in vivo BOEPL-2-S0456 demonstrated receptor mediated uptake in MDA-MB-231 tumor in mice xenografts (Figure 3 ). The dye conjugate also showed non-specific kidney and liver uptake. Since the liver and kidneys are responsible for dye excretion, the fluorescence in these organs was likely due to clearance of the dye conjugate via renal and hepatic routes. Nevertheless, to reduce the scavenging of BOEPL-L2-S0456 by the liver, the PEG linker was replaced by a peptidoglycan linker

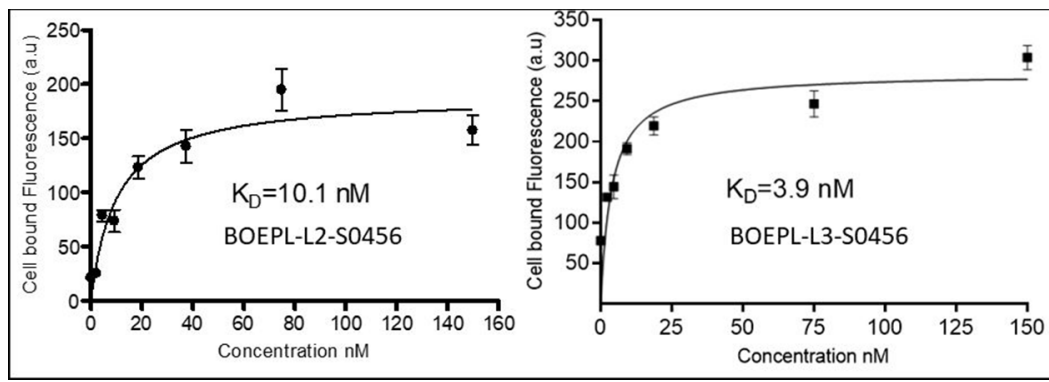

Figure 2: In vitro binding of BOEPL-L2-S0456 and BOEPL-L3-S0456 for MDA-MB-231 breast cancer cells expressing LHRH-R. The cells were incubated with various concentration of the dye conjugates at $37^{\circ} \mathrm{C}$ for $1 \mathrm{~h}$. After incubation cells were washed three times and then dissolved in $1 \%$ SDS. Cell bound fluorescence was measured by fluorimeter.

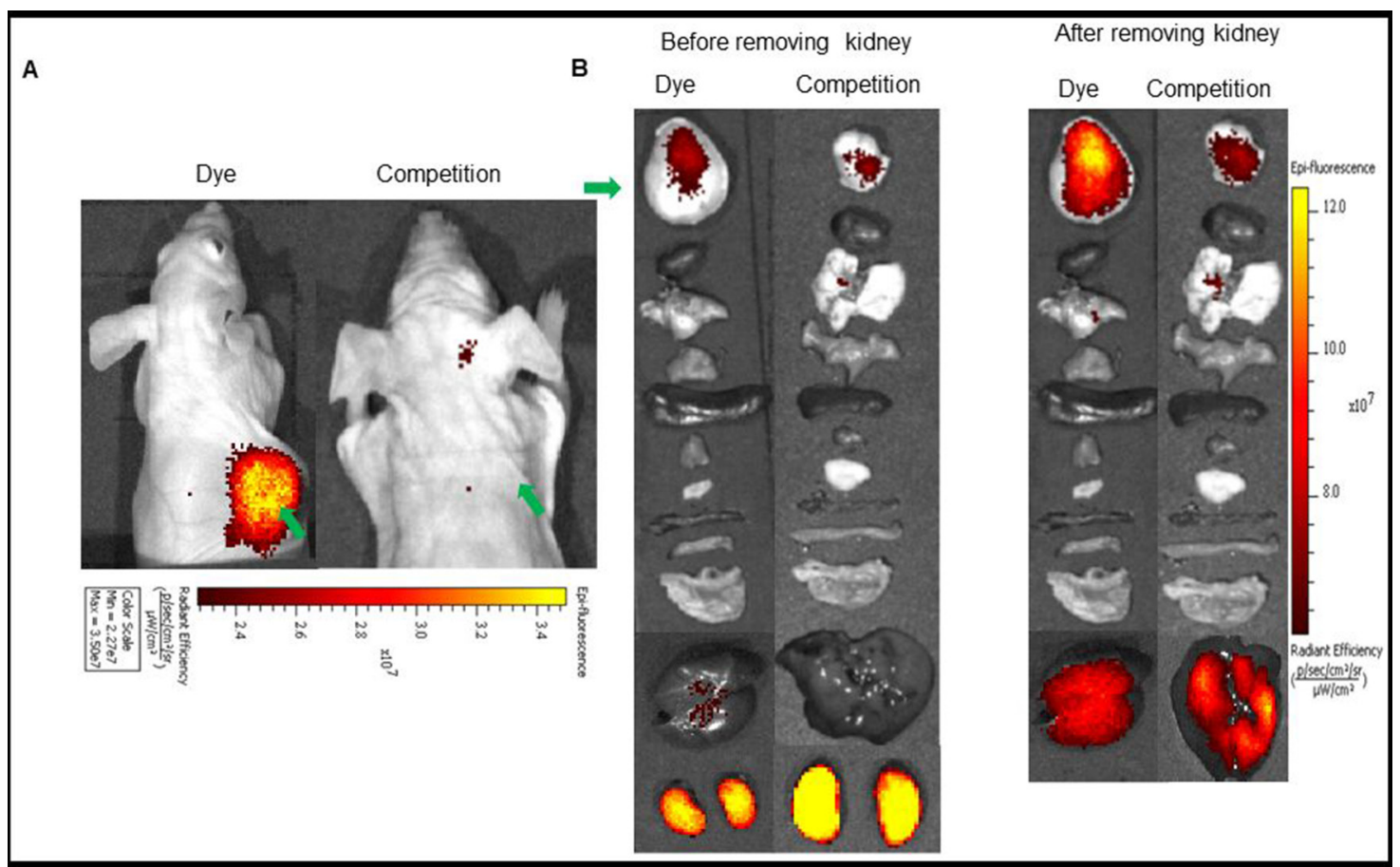

Figure 3: (A) In vivo uptake of the BOEPL-L2-S0456 dye conjugate in MDA-MB-231 tumor xenografts. Mice were treated intravenously with the dye conjugate either in the presence (Competition) or absence (Dye) of 100-fold excess of the unlabeled conjugates. (B) Uptake of BOEPL-L2-S0456 by various organs. All the images were acquired $2 \mathrm{~h}$ post injection. List of organs from top to bottom: Tumor, heart, lungs, pancreas, spleen, muscle, skin, small intestine, large intestine, stomach, liver, and kidney. Green arrow indicates tumor. 
previously shown to reduce liver uptake to yield BOEPLL3-S0456. Importantly, $2 \mathrm{~h}$ post injection, BOEPLL3-S0456 was found to accumulate in the MBA-MB-231 breast cancer tumor but largely avoid liver uptake (Figure 4). Moreover, unlabeled targeting ligand (BOEPL-L3) was able to block the tumor uptake of BOEPL-L3-S0456, confirming that tumor uptake was indeed receptor mediated. Biodistribution study showed that other than the tumor, only kidney exhibited high fluorescence. The fluorescence intensity of the tumor was lower than that of the kidney, but as evidenced in the competition studies, accumulation of the dye conjugate in tumor was receptormediated, whereas that of the kidney was due to excretion of the dye conjugate via the renal route. The ability of BOEPL-L3-S0456 to target receptor-positive tumors was further evaluated by injecting the dye conjugate into mice bearing ovarian cancer (OVCAR-3 tumors, Figure 5) and endometrial xenografts (HEC-1B tumors, Figure 6). In both tumor models, BOEPL-L3-S0456 showed receptormediated uptake and was found to excrete through renal route. Other than tumor and kidney other organs showed little to no signal.

To investigate the retention time of the dye conjugate in the tumor, a time-course study was performed. Mice were injected with 10 nmoles of the dye conjugates and imaged at $2 \mathrm{~h}, 8 \mathrm{~h}$, and $12 \mathrm{~h}$ (Figure 7).

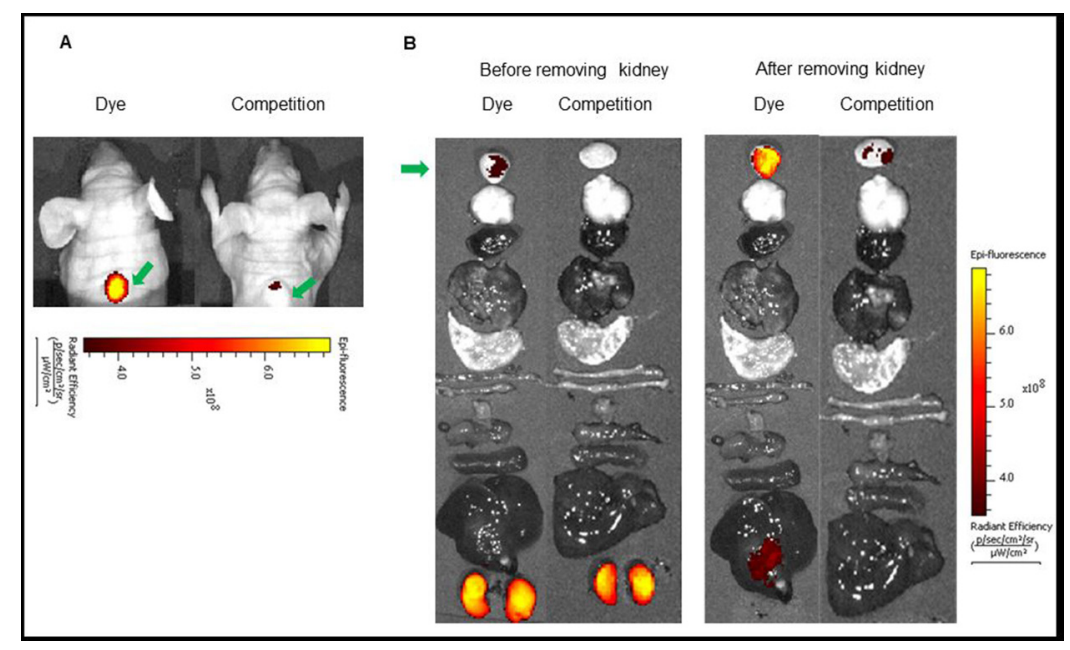

Figure 4: (A) In vivo uptake of the BOEPL-L3-S0456 dye conjugate in MDA-MB-231 tumor xenografts. Mice were treated intravenously with the dye conjugate either in the presence (Competition) or absence (Dye) of 100-fold excess of the unlabeled conjugates. (B) Uptake of BOEPL-L3-S0456 by various organs. All the images were acquired $2 \mathrm{~h}$ post injection. List of organs from top to bottom: Tumor, brain, heart, lungs, stomach, small intestine, large intestine, muscle, pancreas, spleen, liver, and kidney. Green arrow indicates tumor.

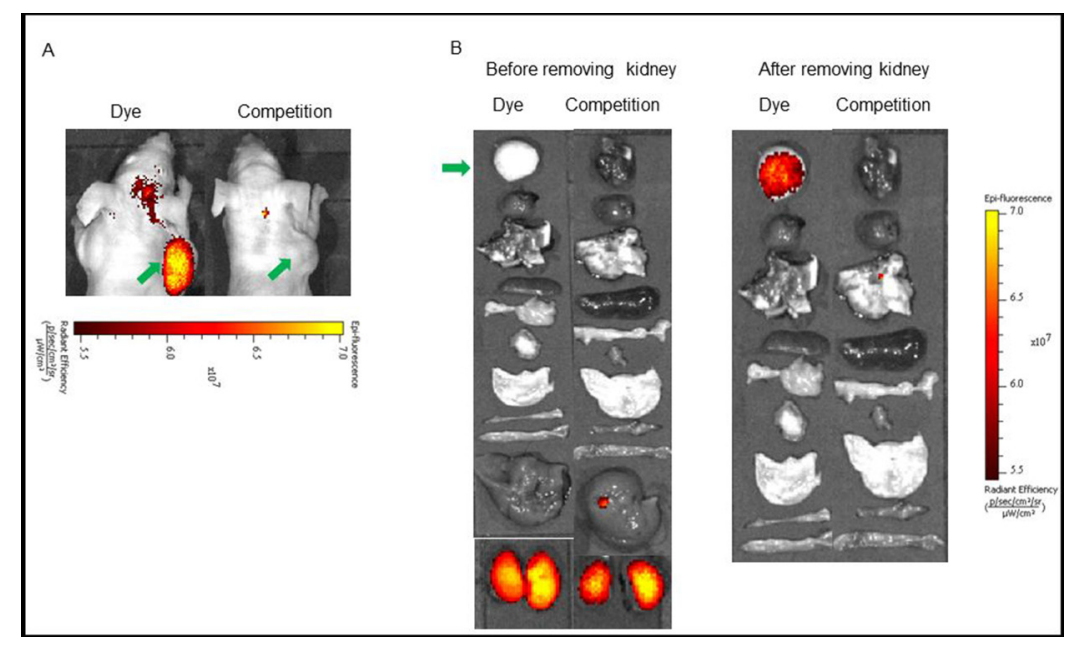

Figure 5: (A) In vivo uptake of the BOEPL-L3-S0456 dye conjugate in OVCAR-3 tumor xenografts. Mice were treated intravenously with the dye conjugate either in the presence (Competition) or absence (Dye) of 100-fold excess of the unlabeled conjugates. (B) Uptake of BOEPL-L3-S0456 by various organs. All the images were acquired $2 \mathrm{~h}$ post injection. List of organs from top to bottom: Tumor, heart, lungs, spleen, pancreas, muscle, stomach, small intestine, large intestine, liver, and kidneys. Green arrow indicates tumor. 
Even after $12 \mathrm{~h}$ post injection, the fluorescence intensity of the tumor was found to be high and only a very slight decrease in the intensity was observed when compared to the image taken $2 \mathrm{~h}$ post injection. In summary, we have been able to synthesize and optimize an LHRH-R targeted fluorescence dye conjugate which not only demonstrates receptor-mediated uptake in the tumor but also shows good tumor retention for at least $12 \mathrm{~h}$ post injection.

\section{DISCUSSION}

Complete surgical resection of a tumor is the most effective way to treat cancers and increase the effectiveness of any necessary adjuvant radio- or chemotherapy. Inefficient surgical resection of tumor can leave behind cancer cells that cause recurrence of the primary tumor and may even lead to metastasis. One of the primary reasons for failure to resect all diseased tissue is the inability of the

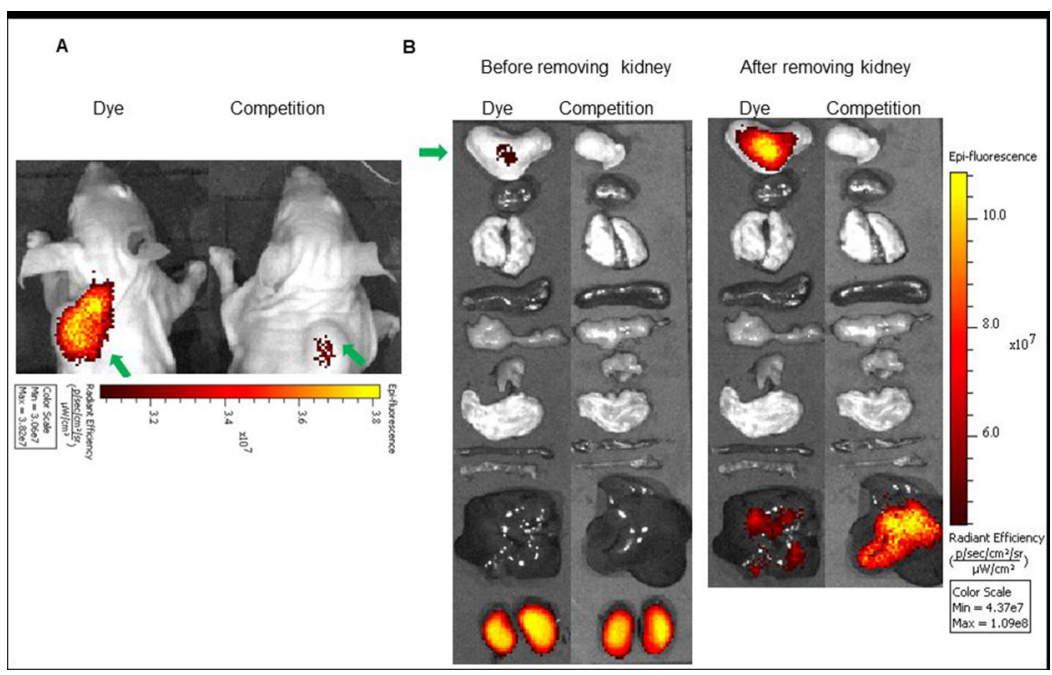

Figure 6: (A) In vivo uptake of the BOEPL-L3-S0456 dye conjugate in HEC-1B tumor xenografts. Mice were treated intravenously with the dye conjugate either in the presence (Competition) or absence (Dye) of 100-fold excess of the unlabeled conjugates. (B) Uptake of BOEPL-L3-S0456 by various organs. All the images were acquired $2 \mathrm{~h}$ post injection. List of organs from top to bottom: Tumor, heart, lungs, spleen, pancreas, muscle, stomach, small intestine, large intestine, liver and kidney. Green arrow indicates tumor.

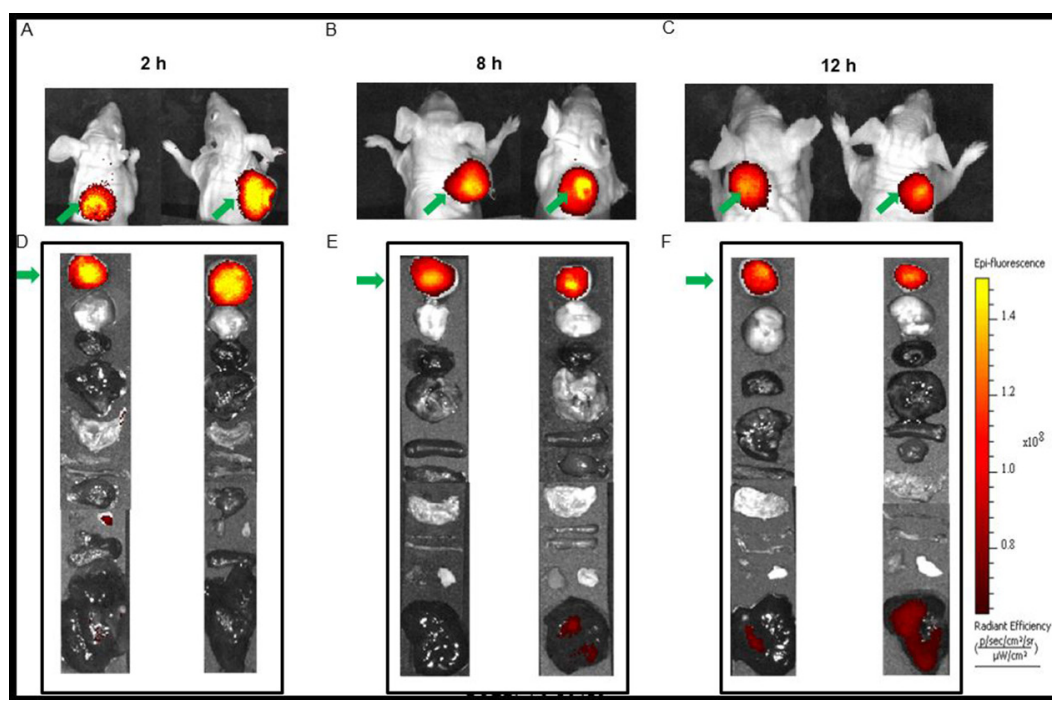

Figure 7: Time course imaging of MDA-MB-231 tumor with BOEPL-L3-S0456. The images were taken at $2 \mathrm{~h}, 8 \mathrm{~h}$, and $12 \mathrm{~h}$ post injection to study the tumor retention of the dye conjugate. Whole body imaging is shown in panels (A-C). Uptake of BOEPL-L3-S0456 by various organs was observed at various time points (D-F). List of organs from top to bottom: Tumor, brain, heart, lungs, stomach, small intestine, large intestine, spleen, pancreas, muscle, skin, and liver. Green arrow indicates tumor. 
surgeon to visually or tactilely differentiate cancer cells from the healthy cells. Fluorescence-guided surgery is an effective way to improve the surgical outcome and patient survival. Currently, there are multiple NIR dye conjugates targeted to various receptors such as the folate receptor, [33, 34] PSMA, [35] CAIX, [36-38] CCK2R, [39-41] and NK1R [42] etc. Despite the availability of these targeted NIR dye conjugates, many cancers cannot be imaged either due to the complete absence of or presence of only very low number of these receptors. Thus, there is an urgent need to develop more targeted NIR dye conjugates so that more cancers can be imaged using them. Since high levels of LHRH-R are found in cancers of the breast $[7,8]$, ovary $[12,14]$, prostate [9-11], and endometrium $[12,13]$ we anticipate that LHRH-R targeted NIR conjugates will be beneficial for surgical resection of these tumors by fluorescence-guided surgery.

An ideal NIR dye conjugate should possess high binding affinity and specificity, high tumor to background ratio, high quantum yield and rapid clearance from the receptor negative tissues. in vitro, BOEPL-L3-S0456 exhibited low nanomolar binding affinity and specificity for LHRH-R. In mouse xenografts, the dye conjugate showed receptor mediated uptake in the tumor, whereas the uptake in the kidney was non-specific and was due to excretion of the conjugate via renal route. The deeper tissue penetration of the NIR light should also facilitate effective resection of malignant tissues buried deeper in healthy tissues. Overall the in vivo results in the mouse models indicate BOEPL-L3-S0456 is a better candidate for optical imaging compared to BOEPL-L2-S0456, and as a consequence displays better potential for eventual use in fluorescence-guided surgery of tumors expressing LHRH-R. To conclude we have been able to demonstrate that a non-peptidic small molecule ligand of LHRH-R can be used to successfully deliver a fluorescent payload specifically to the LHRH-R positive tumors while reducing the uptake amount/retention duration in liver or kidneys.

\section{MATERIALS AND METHODS}

Materials: Benzotriazol-1-yl-oxytripyrrolidinophosphonium hexafluorophosphate (PyBop), N,Ndimethylformamide (DMF), $N$-ethyl- $N$-isopropylpropan-2amine (DIPEA), isopropyl alcohol (IPA,) dichloromethane (DCM), trifluoroacetic acid (TFA), 1,2-ethanedithiol, triisopropylsilane (TIPS), and all other chemical reagents were purchased from Sigma-Aldrich. Cell culture reagents such as Rosswell Park Memorial Institute medium 1640 (RPMI 1640) were purchased from GIBCO, and fetal bovine serum (FBS), 1\% penicillin-streptomycin, $2 \mathrm{mM}$ glutamine were purchased from Life Technologies.

\section{Syntheses}

Synthesis of BOEPL-L2: In each of the syntheses below, modified version of LHRH-R antagonist
(NBI42902 [32]) was used as a targeting ligand because NBI42902 lacked a functional group that could be readily used for further conjugation. We named the modified ligand as BOEPL (Breast, Ovarian, Endometrial, and Prostate Cancer Ligand). Careful observation of structure activity relationship [30] revealed that the ether functionality on the fluorinated aromatic ring of NBI42902 could be substituted without significantly impacting its specificity and affinity for LHRH-R (Figure 1). For the simplicity of conjugation, the ether group was replaced with carboxylic acid and further conjugated to a different linker (L2, or L3) to generate a construct for subsequent conjugation to the near infrared (NIR) fluorescent dye, S0456. The LHRH-R targeting ligand (NBI42902) was synthesized according to published procedures [30], except the ether group on the antagonist was converted to a carboxylic acid for ease of conjugation to a linker.

The modified antagonist, termed BOEPL, was then coupled to a polyethyleneglycol based linker (L2) by solid phase peptide synthesis (Supplementary Figure 1) using standard solid phase chemistry. The final product was cleaved from the resin using a solution of TFA:water:TIPS:ethanedithiol (95\%: 2.5\%: 2.5\%: $2.5 \%$ ). Crude BOEPL-L2 was purified by reverse phaseHPLC $[\mathrm{A}=2 \mathrm{mM}$ ammonium acetate buffer ( $\mathrm{pH}$ 5.0), $\mathrm{B}=$ acetonitrile, solvent gradient $0 \% \mathrm{~B}$ to $80 \% \mathrm{~B}$ in $35 \mathrm{~min}$ ] to yield the desired product. LRMS-LC/MS (m/z): $[\mathrm{M}+\mathrm{H}]^{+}$ calcd for $\mathrm{C}_{47} \mathrm{H}_{61} \mathrm{~F}_{2} \mathrm{~N}_{5} \mathrm{O}_{12} \mathrm{~S}, 958.08$; found 959 .

Synthesis of BOEPL-L3: The highly hydrophilic but uncharged peptidoglycan linker, L3, was synthesized from saccharopeptide subunits described elsewhere [43] using standard solid phase peptide synthesis (Supplementary Figure 2). BOEPL was coupled to the linker on solid phase, and the final product was cleaved from the resin and purified using the methods described above. LRMSLC/MS (m/z): $[\mathrm{M}+\mathrm{H}]^{+}$calcd for $\mathrm{C}_{67} \mathrm{H}_{94} \mathrm{~F}_{2} \mathrm{~N}_{10} \mathrm{O}_{23} \mathrm{~S}, 1477$; found 1478 .

Coupling of the near infrared fluorescent dye, S0456 to BOEPL-L2, and BOEPL-L3: As described in Supplementary Figure 1, 1 equivalent each of S0456maleimide and BOEPL-L2 were dissolved in anhydrous DMSO, followed by addition of 5 equivalents of DIPEA. The reaction mixture was stirred under argon for $1 \mathrm{~h}$ and the progress of the reaction was monitored using LCMS (Supplementary Figure 3). Crude BOEPL-L2-S0456 was purified by RP-HPLC $[\mathrm{A}=2 \mathrm{mM}$ ammonium acetate buffer $(\mathrm{pH} 7.0), \mathrm{B}=$ acetonitrile, solvent gradient $0 \%$ $\mathrm{B}$ to $80 \% \mathrm{~B}$ in $35 \mathrm{~min}$ ] to yield the requisite product. BOEPL-L3-S0456 was synthesized and purified similarly (Supplementary Figures 2 and 4). LCMS characterization of BOEPL-L2-S0456, and BOEPL-L3-S0456 are as follows; LRMS-LC/MS (m/z): $[\mathrm{M}+\mathrm{H}]^{+}$calcd for $\mathrm{C}_{100} \mathrm{H}_{118}$ $\mathrm{F}_{2} \mathrm{~N}_{9} \mathrm{Na}_{3} \mathrm{O}_{28} \mathrm{~S}_{5}, 2161.35$; found 2162. LRMS-LC/MS (m/z): $[\mathrm{M}+\mathrm{H}]^{+}$calcd for $\mathrm{C}_{120} \mathrm{H}_{151} \mathrm{~F}_{2} \mathrm{~N}_{14} \mathrm{Na}_{3} \mathrm{O}_{39} \mathrm{~S}_{5}, 2680.85$; found 2682 respectively.

Cell culture: MDA-MB-231 breast cancer cells, HEC-1B endometrial cancer cells and OVCAR-3 ovarian 
cancer cells (purchased from ATCC) were cultured as a monolayer in RPMI 1640 medium supplemented with 10 $\%$ fetal bovine serum, $1 \%$ of $2 \mathrm{mM}$ glutamine, and $1 \%$ penicillin-streptomycin at $37^{\circ} \mathrm{C}$ in a $5 \% \mathrm{CO}_{2}$ and $95 \%$ humidified atmosphere.

Binding assay: 100,000 MDA-MB-231 or cells were seeded into 24 well plates and allowed to grow to monolayers over $48 \mathrm{~h}$. Spent medium was replaced with fresh medium containing various concentrations of the dye conjugate (BOEPL-L2-S0456 or BOEPL-L3-S0456). After incubation for $1 \mathrm{~h}$ at $37^{\circ} \mathrm{C}$, the cells were washed $3 \mathrm{x}$ with fresh medium and dissolved in $0.5 \%$ SDS. The cell bound fluorescence was measured using a fluorescence spectrophotometer.

Animal husbandry and tumor implantation: All animal procedures were approved by the Purdue Animal Care and Use Committee. Female athymic nu/nu mice, 5-6 weeks of age, were acquired from Harlan Laboratories and maintained on a standard $12 \mathrm{~h}$ light-dark cycle with unlimited access to normal rodent chow and water. When desired, mice were injected subcutaneously in the right hind flank with $5 \times 10^{6}$ MDA-MB-231, OVCAR-3, or HEC-1B cells, and tumors were allowed to grow to 200$300 \mathrm{~mm}^{3}$.

In vivo fluorescence imaging and biodistribution: Following development of subcutaneous tumor xenografts, mice were intravenously injected (via tail vein) with the 10 nanomoles of fluorescence dye conjugate (BOEPLL2-S0456, or BOEPL-L3-S0456) either in the presence or absence of a 100-fold excess of the unlabeled conjugates. Animals were euthanized at various time points post injection by $\mathrm{CO}_{2}$ asphyxiation, and whole-body images were acquired using a Caliper IVIS Luminal II. Organs were then harvested and imaged to quantitate accumulation of conjugate in desired organs. The image acquisition parameters were as follows: i) lamp level-high, ii) excitation-745 nm, iii) emission-ICG, iv) binning (M) 4M, (v) f-stop- 4, (vi) FOV-12.5, (vii) acquisition time, $1 \mathrm{~s}$.

\section{Abbreviations}

LHRH-R (Luteinizing Hormone Releasing Hormone Receptor), NIR (Near Infrared), BOEPL (Breast, $O$ varian, Endometrial, and Prostate Cancer Ligand). Luteinizing hormone (LH), Follicle stimulating hormone (FSH), Benzotriazol-1-yl-oxytripyrrolidinophosphonium hexafluorophosphate (PyBop), N,N-dimethylformamide (DMF), $N$-ethyl- $N$-isopropylpropan-2-amine (DIPEA), Isopropyl alcohol (IPA), Dichloromethane (DCM), Trifluoroacetic acid (TFA), 1,2-ethanedithiol, triisopropylsilane (TIPS), Rosswell Park Memorial Institute medium 1640 (RPMI 1640).

\section{Author contributions}

1. Jyoti Roy: Study conception and design, synthesis of compounds, acquisition of in vitro and in vivo data, analysis and interpretation of data, manuscript drafting, and critical review.

2. Miranda Kaake: Synthesis of compounds, acquisition of in vitro and in vivo data, and analysis.

3. Philip S Low: study conception and design and critical review.

\section{ACKNOWLEDGMENTS AND FUNDING}

Authors would like to thank Endocyte Inc. (West Lafayette, IN) for funding this research project.

\section{CONFLICTS OF INTEREST}

The authors declare no potential conflicts of interest.

\section{REFERENCES}

1. Harrison GS, Wierman ME, Nett TM, Glode LM. Gonadotropin-releasing hormone and its receptor in normal and malignant cells. Endocr Relat Cancer. 2004; 11:725-48. https://doi.org/10.1677/erc.1.00777.

2. McArdle CA, Franklin J, Green L, Hislop JN. Signalling, cycling and desensitisation of gonadotrophin-releasing hormone receptors. J Endocrinol. 2002; 173:1-11.

3. Ruf F, Fink MY, Sealfon SC. Structure of the GnRH receptor-stimulated signaling network: insights from genomics. Front Neuroendocrinol. 2003; 24:181-99. https:// doi.org/10.1016/S0091-3022(03)00027-X.

4. Tieva A, Stattin P, Wikström P, Bergh A, Damber JE. Gonadotropin-releasing hormone receptor expression in the human prostate. Prostate. 2001; 47:276-84. https://doi. org/10.1002/pros.1072.

5. Clayton RN, Catt KJ. Gonadotropin-releasing hormone receptors: characterization, physiological regulation, and relationship to reproductive function. Endocr Rev. 1981; 2:186-209. https://doi.org/10.1210/edrv-2-2-186.

6. Cheung LW, Wong AS. Gonadotropin-releasing hormone: GnRH receptor signaling in extrapituitary tissues. FEBS J. 2008; 275:5479-95. https://doi. org/10.1111/j.1742-4658.2008.06677.x.

7. Limonta $\mathrm{P}$, Montagnani Marelli M, Mai S, Motta M, Martini L, Moretti RM. GnRH receptors in cancer: from cell biology to novel targeted therapeutic strategies. Endocr Rev. 2012; 33:784-811. https://doi.org/10.1210/ er.2012-1014.

8. Nagy A, Schally AV. Targeting of cytotoxic luteinizing hormone-releasing hormone analogs to breast, ovarian, endometrial, and prostate cancers. Biol Reprod. 2005; 73:851-59. https://doi.org/10.1095/biolreprod.105.043489.

9. Cook T, Sheridan WP. Development of GnRH antagonists for prostate cancer: new approaches to treatment. Oncologist. 2000; 5:162-68. https://doi.org/10.1634/ theoncologist.5-2-162. 
10. Shore ND, Abrahamsson PA, Anderson J, Crawford ED, Lange P. New considerations for ADT in advanced prostate cancer and the emerging role of $\mathrm{GnRH}$ antagonists. Prostate Cancer Prostatic Dis. 2013; 16:7-15. https://doi. org/10.1038/pcan.2012.25.

11. Qayum A, Gullick W, Clayton RC, Sikora K, Waxman J. The effects of gonadotrophin releasing hormone analogues in prostate cancer are mediated through specific tumour receptors. Br J Cancer. 1990; 62:96-99. https://doi. org/10.1038/bjc. 1990.236 .

12. Li X, Shen B, Chen Q, Zhang X, Ye Y, Wang F, Zhang X. Antitumor effects of cecropin B-LHRH' on drug-resistant ovarian and endometrial cancer cells. BMC Cancer. 2016; 16:251. https://doi.org/10.1186/s12885-016-2287-0.

13. Chatzaki E, Bax CM, Eidne KA, Anderson L, Grudzinskas JG, Gallagher CJ. The expression of gonadotropin-releasing hormone and its receptor in endometrial cancer, and its relevance as an autocrine growth factor. Cancer Res. 1996; 56:2059-65.

14. Kang SK, Choi KC, Cheng KW, Nathwani PS, Auersperg N, Leung PC. Role of gonadotropin-releasing hormone as an autocrine growth factor in human ovarian surface epithelium. Endocrinology. 2000; 141:72-80. https://doi. org/10.1210/endo.141.1.7250.

15. Friess H, Büchler M, Kiesel L, Krüger M, Beger HG. LH-RH receptors in the human pancreas. Basis for antihormonal treatment in ductal carcinoma of the pancreas. Int J Pancreatol. 1991; 10:151-59.

16. Moretti RM, Montagnani Marelli M, Van Groeninghen JC, Limonta P. Locally expressed LHRH receptors mediate the oncostatic and antimetastatic activity of LHRH agonists on melanoma cells. J Clin Endocrinol Metab. 2002; 87:379197. https://doi.org/10.1210/jcem.87.8.8755.

17. Jaszberenyi M, Schally AV, Block NL, Nadji M, Vidaurre I, Szalontay L, Rick FG. Inhibition of U-87 MG glioblastoma by AN-152 (AEZS-108), a targeted cytotoxic analog of luteinizing hormone-releasing hormone. Oncotarget. 2013; 4:422-32. https://doi.org/10.18632/oncotarget.917.

18. Sion-Vardi N, Kaneti J, Segal-Abramson T, Giat J, Levy J, Sharoni Y. Gonadotropin-releasing hormone specific binding sites in normal and malignant renal tissue. J Urol. 1992; 148:1568-70. https://doi.org/10.1016/ S0022-5347(17)36971-9.

19. Pati D, Habibi HR. Inhibition of human hepatocarcinoma cell proliferation by mammalian and fish gonadotropinreleasing hormones. Endocrinology. 1995; 136:75-84. https://doi.org/10.1210/endo.136.1.7828560.

20. Roy J, Kaake M, Srinivasarao M, Low PS. Targeted Tubulysin B Hydrazide Conjugate for the Treatment of Luteinizing Hormone-Releasing Hormone ReceptorPositive Cancers. Bioconjug Chem. 2018; 29:2208-14. https://doi.org/10.1021/acs.bioconjchem.8b00164.

21. Engel J, Emons G, Pinski J, Schally AV. AEZS-108 : a targeted cytotoxic analog of LHRH for the treatment of cancers positive for LHRH receptors. Expert Opin Investig
Drugs. 2012; 21:891-99. https://doi.org/10.1517/1354378 4.2012.685128.

22. Liu H, Chang S, Sun J, Zhu S, Pu C, Zhu Y, Wang Z, $\mathrm{Xu} \mathrm{RX}$. Ultrasound-mediated destruction of LHRHatargeted and paclitaxel-loaded lipid microbubbles induces proliferation inhibition and apoptosis in ovarian cancer cells. Mol Pharm. 2014; 11:40-48. https://doi.org/10.1021/ mp4005244.

23. Meng J, Fan J, Galiana G, Branca RT, Clasen PL, Ma S, Zhou J, Leuschner C, Kumar CS, Hormes J, Otiti T, Beye AC, Harmer MP, et al. LHRH-functionalized superparamagnetic iron oxide nanoparticles for breast cancer targeting and contrast enhancement in MRI. Mater Sci Eng C Biomim Supramol Syst. 2009; 29:1467-79. https://doi.org/10.1016/j.msec.2008.09.039.

24. Gao F, Cai P, Yang W, Xue J, Gao L, Liu R, Wang Y, Zhao Y, He X, Zhao L, Huang G, Wu F, Zhao Y, et al. Ultrasmall $[(64) \mathrm{Cu}] \mathrm{Cu}$ nanoclusters for targeting orthotopic lung tumors using accurate positron emission tomography imaging. ACS Nano. 2015; 9:4976-86. https://doi. org/10.1021/nn507130k.

25. Hao D, Sun L, Hu X, Hao X. 99mTc-LHRH in tumor receptor imaging. Oncol Lett. 2017; 14:569-78. https://doi. org/10.3892/ol.2017.6246.

26. Saad M, Garbuzenko OB, Ber E, Chandna P, Khandare JJ, Pozharov VP, Minko T. Receptor targeted polymers, dendrimers, liposomes: which nanocarrier is the most efficient for tumor-specific treatment and imaging? J Control Release. 2008; 130:107-14. https://doi. org/10.1016/j.jconrel.2008.05.024.

27. Curtis KK, Sarantopoulos J, Northfelt DW, Weiss GJ, Barnhart KM, Whisnant JK, Leuschner C, Alila H, Borad MJ, Ramanathan RK. Novel LHRH-receptor-targeted cytolytic peptide, EP-100: first-in-human phase I study in patients with advanced LHRH-receptor-expressing solid tumors. Cancer Chemother Pharmacol. 2014; 73:931-41. https://doi.org/10.1007/s00280-014-2424-x.

28. Karampelas T, Argyros O, Sayyad N, Spyridaki K, Pappas C, Morgan K, Kolios G, Millar RP, Liapakis G, Tzakos AG, Fokas D, Tamvakopoulos C. GnRH-Gemcitabine conjugates for the treatment of androgen-independent prostate cancer: pharmacokinetic enhancements combined with targeted drug delivery. Bioconjug Chem. 2014; 25:813-23. https:// doi.org/10.1021/bc500081g.

29. Vegt E, Melis M, Eek A, de Visser M, Brom M, Oyen WJ, Gotthardt M, de Jong M, Boerman OC. Renal uptake of different radiolabelled peptides is mediated by megalin: SPECT and biodistribution studies in megalin-deficient mice. Eur J Nucl Med Mol Imaging. 2011; 38:623-32. https://doi.org/10.1007/s00259-010-1685-9.

30. Hosseinimehr SJ, Tolmachev V, Orlova A. Liver uptake of radiolabeled targeting proteins and peptides: considerations for targeting peptide conjugate design. Drug Discov Today. 2012; 17:1224-32. https://doi.org/10.1016/j. drudis.2012.07.002. 
31. Srinivasarao M, Galliford CV, Low PS. Principles in the design of ligand-targeted cancer therapeutics and imaging agents. Nat Rev Drug Discov. 2015; 14:203-19. https://doi. org/10.1038/nrd4519.

32. Tucci FC, Zhu YF, Struthers RS, Guo Z, Gross TD, Rowbottom MW, Acevedo O, Gao Y, Saunders J, Xie Q, Reinhart GJ, Liu XJ, Ling N, et al. 3-[(2R)-Amino2-phenylethyl]-1-(2,6-difluorobenzyl)-5-(2-fluoro-3methoxyphenyl)- 6-methylpyrimidin-2,4-dione (NBI 42902) as a potent and orally active antagonist of the human gonadotropin-releasing hormone receptor. Design, synthesis, and in vitro and in vivo characterization. J Med Chem. 2005; 48:1169-78. https://doi.org/10.1021/ jm049218c.

33. De Jesus E, Keating JJ, Kularatne SA, Jiang J, Judy R, Predina J, Nie S, Low P, Singhal S. Comparison of Folate Receptor Targeted Optical Contrast Agents for Intraoperative Molecular Imaging. Int J Mol Imaging. 2015; 2015:469047. https://doi.org/10.1155/2015/469047.

34. Hoogstins CE, Tummers QR, Gaarenstroom KN, de Kroon CD, Trimbos JB, Bosse T, Smit VT, Vuyk J, van de Velde CJ, Cohen AF, Low PS, Burggraaf J, Vahrmeijer AL. A Novel Tumor-Specific Agent for Intraoperative Near-Infrared Fluorescence Imaging: A Translational Study in Healthy Volunteers and Patients with Ovarian Cancer. Clin Cancer Res. 2016; 22:2929-38. https://doi. org/10.1158/1078-0432.CCR-15-2640.

35. Wang X, Huang SS, Heston WD, Guo H, Wang BC, Basilion JP. Development of targeted near-infrared imaging agents for prostate cancer. Mol Cancer Ther. 2014; 13:2595-606. https://doi.org/10.1158/1535-7163. MCT-14-0422.

36. Lv PC, Roy J, Putt KS, Low PS. Evaluation of a Carbonic Anhydrase IX-Targeted Near-Infrared Dye for Fluorescence-Guided Surgery of Hypoxic Tumors. Mol Pharm. 2016; 13:1618-25. https://doi.org/10.1021/acs. molpharmaceut.6b00065.
37. Kijanka MM, van Brussel AS, van der Wall E, Mali WP, van Diest PJ, van Bergen En Henegouwen PM, Oliveira S. Optical imaging of pre-invasive breast cancer with a combination of VHHs targeting CAIX and HER2 increases contrast and facilitates tumour characterization. EJNMMI Res. 2016; 6:14. https://doi.org/10.1186/ s13550-016-0166-y.

38. Li J, Bao B, Liu L, Wang X. Near-Infrared Fluorescence Imaging of Carbonic Anhydrase IX in Athymic Mice Bearing HT-29 Tumor Xenografts. Biomed Res Int. 2016; 2016:6825712. https://doi.org/10.1155/2016/6825712.

39. Wayua C, Low PS. Evaluation of a cholecystokinin 2 receptor-targeted near-infrared dye for fluorescence-guided surgery of cancer. Mol Pharm. 2014; 11:468-76. https://doi. org/10.1021/mp400429h.

40. Wayua C, Roy J, Putt KS, Low PS. Selective Tumor Targeting of Desacetyl Vinblastine Hydrazide and Tubulysin B via Conjugation to a Cholecystokinin 2 Receptor (CCK2R) Ligand. Mol Pharm. 2015; 12:2477-83. https://doi.org/10.1021/acs.molpharmaceut.5b00218.

41. Roy J, Putt KS, Coppola D, Leon ME, Khalil FK, Centeno BA, Clark N, Stark VE, Morse DL, Low PS. Assessment of cholecystokinin 2 receptor (CCK2R) in neoplastic tissue. Oncotarget. 2016; 7:14605-15. https://doi.org/10.18632/ oncotarget.7522.

42. Kanduluru AK, Srinivasarao M, Low PS. Design, Synthesis, and Evaluation of a Neurokinin-1 ReceptorTargeted Near-IR Dye for Fluorescence-Guided Surgery of Neuroendocrine Cancers. Bioconjug Chem. 2016; 27:215765. https://doi.org/10.1021/acs.bioconjchem.6b00374.

43. Vlahov IR, Santhapuram HK, You F, Wang Y, Kleindl PJ, Hahn SJ, Vaughn JF, Reno DS, Leamon CP. Carbohydratebased synthetic approach to control toxicity profiles of folate-drug conjugates. J Org Chem. 2010; 75:3685-91. https://doi.org/10.1021/jo100448q. 